$£ 51,000$ and the following awards have been made. Nuffield Professorial Research Fellowship in Gerontology: Dr. P. L. Krohn, reader in endocrinology, University of Birmingham. Dr. Krohn has taken up his appointment, and his programme of research, aimed at "a causal analysis of the process of ageing", includes a study of the interactions of tissues and their environments (chiefly by grafting tissues of animals of one age into animals of another age), and a study of the factors controlling the duration of reproductive life in primates. This appointment is for five years in the first place and is renewable. Nuffield Gerontological Research Fellowship: Dr. D. A. Hall, lecturer in medical biochemistry, University of Leeds. Dr. Hall will take up his fellowship on January 1, 1954. He proposes to study the changes in connective tissue associated with ageing. This appointment is for three years in the first instance.

\section{Vacation Course in Synoptic Meteorology}

Srnce 1950, when the pioneer course was held, the Royal Meteorological Society, in conjunction with the Council for the Promotion of Field Studies, has held a vacation course in elementary synoptic meteorology yearly at the Council's field-centre at Malham Tarn. The fourth such course took place this year during September 9-16 and was attended by some thirty students. There was the usual wide cross-section of ages and occupations. The instructors were Mr. James Paton (director of the course), Scottish secretary of the Royal Meteorological Society and senior lecturer in meteorological physics at the University of Edinburgh, and Mr. C. D. Ovey, a vice-president of the Royal Meteorological Society and lecturer in geography in the University of Cambridge. Visiting lecturers included Mr. F. E. Lumb, senior meteorological officer at the the Air Traffic Control Centre, Preston, who spoke on the organization of a meteorological station; Prof. R. F. Peel, of the Geography Department, University of Leeds, who gave a talk on the work of the Ruwenzori Expedition, Central Africa; Mr. N. Pye, lecturer in geography in the University of Manchester, who showed a film taken on a recent visit to the arid zone of Arizona; and Mr. R. G. Veryard, secretary of the Royal Meteorological Society and assistant director of the Meteorological Office at Harrow, who gave a lecture on certain aspects of climatology. Practical aspects of the course consisted of observation work; the Malham Tarn Field Centre is well equipped for this purpose, many of the necessary instruments having recently been provided, on permanent loan to the Centre, through the generosity of various instrument manufacturers. Various education authorities and the Education Department of the R.A.F. made it possible for some of the students to attend the course, which is approved for grants in suitable cases. A similar course will be held in late August 1954-a little earlier than this year so that more members of school teaching staffs and sixth-form students will be able to attend before the autumn term begins.

\section{"Flying Saucers"}

IN an article in Science $(118 ; 1953)$, C. C. Wylie, of the State University of Iowa, describes his investigations into the 'flying saucers' which have been much observed in the United States. Wylie concludes that these are simply reflected sunlight, having the following characteristics: (1) they are seen only when the sun is shining; (2) they are generally seen in the part of the sky opposite the sun; (3) there is only one sighting on each saucer, as the area for the critical angle is small.

\section{Oil Pollution of the Sea}

AN international meeting of private citizens representing ten nations is to be held in London on October 27 next to press for action on the evil caused by oil pollution of the sea. The meeting will be held in the lecture hall of the Institution of Electrical Engineers, Savoy Place, London, W.C.2, from 11 a.m. to $4.30 \mathrm{p.m}$. The conference has been convened by the independent committee which has been working for the past two years to arouse public opinion on the need for action on the subject. The committee's task has been greatly assisted by the publication of an official report made to the Minister of Transport during the summer, which reached the conclusion that the only effective way of solving the problem was to prohibit ships from discharging waste oil into the sea. To achieve this, international agreement would be necessary. The purpose of the conference is to bring the findings of the report before public opinion in all countries. The chairman of the meeting will be Mr. James Callaghan, M.P., and the Minister of Transport will open the conference. Other speakers will include Mr. D. F. Anderson (chairman of the General Council of British Shipping), Lord Hurcomb, Sir Douglas Ritchie (chairman of the executive committee, Dock and Harbour Authorities' Association), Mr. Mogens Black (director of the Port of Copenhagen), M. Leon Lippens (mayor of Knokke, Belgium), Mr. Banks Belt (chairman of the Atlantic Waterfowl Council, New York) and Prof. J. Berlioz (Natural History Museum, Paris). A number of local authorities are sending representatives, and the Minister of Housing and Local Government has stated he will be prepared to sanction, on application, the expenses of one delegate to attend the conference from local authorities whose boundaries form part of the coastline. Admission will be by ticket only, which can be obtained by sending a stamped, addressed envelope to Miss P. Barclay-Smith, Secretary, Co-ordinating Advisory Committee on Oil Pollution of the Sea, I.C.B.P. (British Section), c/o British Museum (Natural History), Cromwell Road, London, S.W.7.

\section{Modern Science and Christian Thought}

A course of ten lecture-discussions designed to explore the contemporary form of the relation between science and religion is being held at St. Anne's House, Soho (57 Dean Street, London, W.1), on successive Thursdays until December 17 (October 22 excepted) at 6.30 p.m. The first lecture-on the history of the debate between science and religionwas given on October 8 , and the future meetings will consider the following topics: creation and the expanding universe (Prof. C. A. Coulson); the scientific approach to historical study and Christian presuppositions about history (Miss C. V. Wedgwood); body, brain, mind and spirit-modern physiology in relation to the incarnational view of man; the scientific approach to psychology and Christian pre. suppositions about human nature--a dialogue between a psychologist and a Christian philosopher; the scientific approach to social science and Christian presuppositions about human relations-a dialogue between Prof. H. B. Acton and Prof. Michael Fogarty; man and evolution-modern biological science in 